\title{
Efficacy of Application of Vegetable Seed Oils as Grain Protectant against Infestation by Callosobruchus chinensis and Its Effect on Milling Fractions and Apparent Degree of Dehusking of Legume-Pulses
}

\author{
Dheeraj Mishra ${ }^{1}$, A.K. Shukla ${ }^{2}$, Kamal K. Tripathi ${ }^{1}$,
} A. Singh ${ }^{1}$, A.K. Dixit ${ }^{3}$ and K. Singh ${ }^{1 *}$

${ }^{1}$ Department of Biochemical Engineering and Food Technology, Harcourt Butler Technological Institute (Kanpur - 208 002, INDIA)

${ }^{2}$ M/s. Ambika Solvex Limited (Indore - 452 001, INDIA)

${ }^{3}$ Department of Chemistry, V.S.S.D. Collage (Kanpur - 208 002, INDIA)

\begin{abstract}
The solvent extracted vegetable seed oils of Cucurbitaceae family viz. Bitter gourd (Momordica charentia), Small bitter gourd (Momordica dioica), Bottle gourd (Lagenaria siscraria) and Ridge gourd (Luffa acutangula) were evaluated as grain protectant against callosobruchus chinensis on the stored legume-pulse grains. All the vegetable seed oils were found effective as legume-pulse grain protectant, which provided, negligible weight loss at the oil-application rate of $6-8 \mathrm{~mL} / \mathrm{kg}$ in legume-pulse grain after 60 days storage at laboratory conditions. The milling yield and degree of dehusking gets improved after the oil application. The use of solvent extracted Small bitter gourd seed oil at the level of 6-8 $\mathrm{mL} / \mathrm{kg}$ of legumepulse grain sample resulted in the improved apparent degree of dehusking from 40.0 to $72.59,59.88$ to 92.44, 63.39 to 87.50 and 57.0 to 79.43 for Pigeonpea (Canjanus cajan), Chickpea (Cicer arietinum), Urdbean (Phaseolus mungo) and Mungbean (Phaseolus radiatus), respectively.
\end{abstract}

Key words: insecticide, vegetable oil, pulse, bitter gourd, small bitter gourd, ridge gourd, pigeonpea, chickpea, urdbean, mungbean

\section{INTRODUCTION}

In stored grains, insect damage may account for $10-40 \%$ of loss world-wide ${ }^{1)}$. Fumigation is one of the most effective methods for protection of stored food grains from insect infestation. However, there have been repeated indication that certain insects have developed resistance to commercially available synthetic fumigants apart from risks associated with the use of these toxics chemicals ${ }^{2,33}$. The insecticidal residues left over from these chemicals are also reported to be harmful to human beings as well as to mammals. In the current scenario, there is an urgent need of development of safe alternative which have potential to replace such toxic fumigants and are convenient to use also.

\begin{abstract}
The effectiveness of many botanicals against stored grain insects has already been demonstrated. Many types of spices and herbs are known to possess anti-insect activity especially in the form of essential oils ${ }^{4-6}$. Toxic effects of many monoterpenes from essential oils like d-limonene, linalool and terpeneol were observed in several insects damaging stored products ${ }^{7}$. The use of plant insecticides being safe, easily biodegradable and practically innocuous to non-target species, has drawn attention all over the world. Apart from the known plant insecticides such as pyrethrins, rotenone, nicotine etc., there are many possibilities to use various other plant products like vegetable seed oils for the purpose ${ }^{8-10)}$.
\end{abstract}

Amongst several insects Callosobruchus chinensis is

\footnotetext{
* Correspondence to: K. Singh, Department of Biochemical Engineering and Food Technology, Harcourt Butler Technological Institute, Kanpur-208 002, INDIA

E-mail: dh_mishra@rediffmail.com, avanish_06@rediffmail.com Accepted August 28, 2006 (received for review July 18, 2006)
}

Journal of Oleo Science ISSN 1345-8957 print / ISSN 1347-3352 online

http://jos.jstage.jst.go.jp/en/ 
one of the major insect damaging, the legume-pulse grain, which alone is responsible for an average of 32-64\% loss under storage conditions in different parts of India ${ }^{11-13)}$. Infestation may reach $100 \%$ within 3-5 months of storage. Damaged seed looses its weight as well as market value and it is generally unacceptable for human consumption also. To protect the stored legume pulse grain against insects, many method may be used. Grain can be mixed with ash, and/or other dry fine substances that fill up the inter space between grains and provide a barrier to insect movement ${ }^{14}$. Fresh dry or processed plant materials can be applied as insecticides or to repel the pest insects.

The development of synthetic pesticides has limited over the widespread use of botanical insecticides. These problems makes it necessary to reconsider the potential of traditional methods such as the use of locally available plant material \& plant products which could offer a solution for the quality \& quantity damage done by Callosobruchus chinensis and be a non-damaging to non-target organisms including mammals. The products are biodegradable and thus unlike to have long term hazardous effects on the environment. On the other hand the conventional milling of Pigeonpea, Urdbean and Mungbean having with tightly adhering and slippery seed coats provide 12-18\% lesser than theoretically possible yields of head dhal due to excessive breakage and scouring losses. Vegetable oil application/smearing as pre milling treatment helps to some extent in the reduction of breakage \& scouring losses. The present study has been undertaken to overcome all these problems. The vegetable seed oils of Cucurbitaceae family has been taken for the study, as cucurbits form an important group of vegetable crops and are easily available in rural areas of India. The seed oils of this family are not generally used in daily practice in one or another form neither as edible oil nor as pesticide. Bio-chemically the cucurbits are characterized by bitter principles, called curbitacins. A systematic search for these substances in the family indicates that great majority of species contain bitter principles in some portion of the plant e.g. seed, leaf, flower etc. at some stage of development. Chemically cucurbitacins are tetracyclic triterpenes having extensive oxidation level. They occur in nature, free as glycosides or in complicated mixture $(\mathrm{s})^{15)}$. The effect of seed oils of Small bitter gourd (Momordica dioica), Bitter gourd (Momordica charantia), Bottle gourd (Lagenaria siscraria) and Ridge gourd (Luffa acutangula) as grain protectant against Callosobruchus chinensis, as well as in improving milling quality of legume pulses has been studied.

\section{EXPERIMENTAL}

Four vegetable seed oils of Cucurbitaceae family, viz. Bitter gourd (Momordica charantia), Small bitter gourd
(Momordica dioica), Bottle gourd (Lagenaria siceraria), Ridge gourd (Luffa acutangula) were taken for experimental work. Seeds of Bitter gourd, Bottle gourd and Ridge gourd were collected from the field of Kannauj district, Uttar Pradesh, India and Small bitter gourd seeds from Jalaun district of Bundelkhand region Uttar Pradesh, India. Experimental legume pulse grains of Pigonpea (Cajanus cajan), Chickpea (Cicer arietinun), Urdbean (Phaseolus mungo) and Mungbean (Phaseolus radiatus) were procured from Indian Institute of Pulses Research (IIPR), Kalyanpur, Kanpur, Uttar Pradesh, India and were kept in air tight closed containers at room temperature during its experimental use. The seeds of Bottle gourd, Bitter gourd, Ridge gourd and Small bitter gourd were pre-dried separately in an Yorco Hot Air Oven at $40 \pm 2^{\circ} \mathrm{C}$ as it makes the experimental samples easier to grind for better oil-extraction, breaks fat-water emulsions to make fat dissolve easily in the organic solvent and helps in release of free fat from the tissues of foods ${ }^{16}$. After drying seeds were grinded thoroughly in an electric grinder. The grinded seeds were extracted serially in an Automatic Oil- Extracting Machine SOCS PLUS, Model SCS- 6, of Pelican Equipment, Chennai, India, using petroleum ether $\left(60-80^{\circ} \mathrm{C}\right)$ as a solvent.

Cleaned and graded samples of experimental legumepulse grains having Cotyleadon, Germ, Husk and Moisture as $86.3 \%, 1.2 \% 12.5 \%$ and $7.5 \%$ for Pigeonpea; $82.2 \%, 1.6 \%$, $16.2 \%$ and $10.0 \%$ for Chickpea; $87.1 \%, 1.9 \%, 11.0 \%$ and $11.5 \%$ for Urdbean and $88.0 \%, 1.3 \%, 10.7 \%$ and $8.7 \%$ for Mungbean, respectively, were treated with vegetable seed oils in varying amount i.e. $0.0,2.0,4.0,6.0$ and $8.0 \mathrm{~mL} / \mathrm{kg}$ of sample. These samples were kept in plastic jars having 1012 pin-holes for air circulation. Oils were applied with the help of pipette, dropping the oils in circular fashion and continuous stirring the legume-pulse grains with the help of glass rod. Continuous stirring facilitated even distribution of oils on the surface of legume-pulse grain sample. Control sample were not treated with oils. Three replications for each treatment were made.

After oil application as mentioned above adult pulse beetles "Bruchid" (Callosobruchus chinensis) which were procured from Department of Entomology, Indian Institute of Pulses Research, Kalyanpur, Kanpur, India were introduced in each jar. In this study 10 adults of bruchid, (50\% male \& $50 \%$ female) were introduced in each sample with the help of aspirator. The aspirator was prepared by inserting a two hole cork in a conical flask attaching plastic tubes in the holes. One tube was put in bruchid culture and from other tube adults were sucked. When 10 adults came in the flask the cork was removed and the adults were likewise transferred to each sample. These treated and controlled samples were kept at room temperature for observation of insect emergence. The average time for bruchid to complete one life cycle is $25-30$ days. Therefore, the sample were kept for 30 days to let them reproduce next 
generation and for next 30 days to infest the grains. The observation for weight loss and milling quality of stored legume-pulse were assessed by estimating Apparent Degree of Dehusking as well as Broken, Germ and powder fractions. For weight loss determination, the weight of each jar containing grain sample and Bruchid, were taken initially was recorded, then each jar was opened after storage period and the content grain sample were sieved through a sieve (mesh size 280 ISS Test Sieve). By sieving the powder of grains formed by bruchid as wells the dead and alive Bruchid were separated out manually and the remaining grain sample were again transferred to jar and weighed. The difference in these two weights of grain in the jar provides the weight loss of grain sample.

After determining the weight loss caused by insects all the grain samples (treated and control) were pitted and milled in TM-05 SATAKE Grain Testing Mill (Satake Engineering Co. Ltd., JAPAN) the pitting was done by passing the grains 3 -times through the mill without holding in the mill. It is believed that pitting creates fissures/crack in the outer covering i.e. seed coat of the grain. The cracks help and improve the effectiveness of the milling. These pitted grains were further milled for $10 \pm 2$ seconds in aforementioned mill in one pass. Dehusked whole grain (DWG), Undehusked whole grain (UWG), Partially dehusked whole grain (PDW), Dehusked splits (DS), Undehusked splits (US), Partially dehusked split (PDS), Broken + Germ + Powder (BGP) and Clean husk (CH) were sorted out manually from the milled legume-pulse samples and percent milling fraction were calculated.

Clean husk obtained as a milling fraction and the total husk content in the experimental grain provided the degree of dehusking. As very fine fragments of husk were also present in the powder fraction, therefore the degree of dehusking was denoted as "Apparent Degree of Dehusking" which can be calculated as:

Apparent degree of

dehusking (\%)

$$
=\frac{\text { Clean husk obtained in milling }}{\text { Native husk content of sample milled }} \times 100
$$

On the basis of weight loss in stored grain its apparent degree of dehusking as well as percent milling fraction obtained, the efficacy of application of vegetable seed oils as grain protectant against infestation by Collosobruchus chinensis was assessed.

The statistical analysis of data thus obtained was done with the help of "Indostat Statistical Software Packages" developed by Khetan M.M. (1998) of Indostat services Hyderabad (INDIA).

\section{RESULTA AND DISCUSSION}

The weight loss occurred in kernel damage due to insect infestation in experimental Pigeonpea, Chickpea, Urdbean and Mungbean grains are given in Table 1. It is also apparent from the data that in control samples in which extracted vegetable seed oils were not applied $(0.0 \mathrm{~mL} / \mathrm{kg})$ undergone maximum grain kernel damage i.e. 5.95, 7.50, 5.15 and $5.00 \%$ for Pigeonpea, Chickpea, Urdbean and Mungbean, respectively. It is apparent from the Table 1 that application of experimental vegetable seed oils at the rate of 2.0,4.0, 6.0 and $8.0 \mathrm{~mL} / \mathrm{kg}$ of sample have provides weight loss in the range of 0-3.7, 0-4.2, 0-3.6 and 0-3.4\% for Pigeonpea, Chickpea, Urdbean and Mungbean, respectively. From the Table 1 it is also clear that seed oil dose at the rate of 6.0 and $8.0 \mathrm{~mL} / \mathrm{kg}$ is quite effective, yielding minimum/ negligible weight loss for all the experimental legume-pulse grains, However, use of Small bitter gourd seed oil at the level of $6 \mathrm{~mL} / \mathrm{kg}$ yielded $0.0 \%$ weight loss in case of Pigonpea, Chickpea, Mungbean and $0.10 \%$ weight loss in case of Urdbean. The weight loss in case of application of Small Bitter gourd seed oil at the rate of $4.0 \mathrm{~mL} / \mathrm{kg}$ was found to be minimum as compared to other experimental vegetable seed oils.

The effect of vegetable seed oil application at different levels and storage at laboratory conditions for 60 days followed by 3-pass pitting and 1-pass milling for $12 \pm 2 \mathrm{sec}^{-}$ onds in TM-05 SATAKE Grain Testing Mill on milling fraction of Pigeonpea grains and apparent degree of dehusking are given in Table 2. It was observed that increasing the quantity $(\mathrm{mL} / \mathrm{kg})$ of vegetable seed oil application increases the Dehusked whole grain (DWG) and Dehusked splits (DS) of experimental Pigeonpea grain. The Broken + Germ + Powder (BGP) fraction decreases with increase in applied oil dose. The fraction of BGP was maximum i.e. 23.8\% in control sample because of kernel damage due to insect infestation. The apparent degree of dehusking was observed to be in increasing trend which may be due to the penetration and smearing of oil in the inter-space between husk and cotyledon, which inturn help checks the infestation and facilitates in the easy removal of husk. It is apparent that the dose level of $6-8 \mathrm{~mL} / \mathrm{kg}$ of Ridge gourd seed oil and Small bitter gourd seed oil is optimum which yielded minimum, BGP i.e. $7.9 \%$ \& $7.3 \%$ as well as $7.1 \% \& 6.9 \%$, respectively. The apparent degree of dehusking was observed maximums $71.85 \%$ \& $72.59 \%$ for Ridge gourd seed oil treated experimental samples and 72.59\% for Small bitter gourd seed oil treated samples.

Likewise the experimental samples of Chickpea were also treated with vegetable seed oils in the same fashion as Pigeonpea and were pitted and milled. The effect of vegetable seed oil application at different levels on milling fraction and apparent degree of dehusking of Chickpea are given in Table 3. It is clear from the table that with increase in dose $(\mathrm{mL} / \mathrm{kg})$ of vegetable seed oil, the BGP 
fraction reduces while dehusked whole and splits fraction increases. A dose level of $8 \mathrm{~mL} / \mathrm{kg}$ of Ridge gourd seed oil and Small bitter gourd seed oil was found to be preferably suitable as it provides $94.44 \%$ apparent degree of dehusking in both the cases and minimum 7.0 and $7.4 \%$, BGP, respectively. The effect of application of different doses of vegetable seed oil on milling characteristics of Urdbean and Mungbean are given in Table 4 and Table 5, respectively. The data obtained for both the pulse grains are comparable to the trend as observed in the case of Pigeonpea

Table 1 Average Percent Weight Loss of Legume-Pulse Grain due to Calosobruchus chinensis Infestation (after 60 days of storage).

\begin{tabular}{|c|c|c|c|c|c|c|}
\hline \multirow{2}{*}{ Set No. } & \multirow{2}{*}{$\begin{array}{c}\text { Vegetable Seed } \\
\text { oil used }\end{array}$} & \multirow{2}{*}{ Dose level $(\mathrm{mL} / \mathrm{kg})$} & \multicolumn{4}{|c|}{$\%$ Weight Loss ${ }^{a}$} \\
\hline & & & Pigeonpea & Chickpea & Urdbean & Mungbean \\
\hline \multirow[t]{6}{*}{ A } & \multirow[t]{5}{*}{ Bitter gourd $\left(\mathrm{O}_{1}\right)$} & D0 & 5.95 & 7.50 & 5.15 & 5.00 \\
\hline & & D1 & 3.50 & 3.90 & 3.25 & 3.10 \\
\hline & & D2 & 0.25 & 1.60 & 0.40 & 0.80 \\
\hline & & D3 & 0.10 & 0.40 & 0.25 & 0.30 \\
\hline & & D4 & 0.00 & 0.00 & 0.00 & 0.00 \\
\hline & Mean & & 1.96 & 2.68 & 1.81 & 1.84 \\
\hline \multirow[t]{6}{*}{$\mathrm{B}$} & \multirow{5}{*}{ Small bitter gourd $\left(\mathrm{O}_{2}\right)$} & D0 & 5.95 & 7.50 & 5.15 & 5.00 \\
\hline & & D1 & 3.00 & 3.11 & 3.10 & 3.00 \\
\hline & & $\mathrm{D} 2$ & 0.15 & 0.36 & 0.50 & 0.60 \\
\hline & & D3 & 0.00 & 0.00 & 0.10 & 0.00 \\
\hline & & D4 & 0.00 & 0.00 & 0.00 & 0.00 \\
\hline & Mean & & 1.82 & 2.18 & 1.76 & 1.74 \\
\hline \multirow[t]{6}{*}{$\mathrm{C}$} & \multirow[t]{6}{*}{ Bottle gourd $\left(\mathrm{O}_{3}\right)$} & D0 & 5.95 & 7.50 & 5.15 & 5.00 \\
\hline & & D1 & 3.60 & 4.00 & 3.60 & 3.40 \\
\hline & & D2 & 0.50 & 1.90 & 1.00 & 0.80 \\
\hline & & D3 & 0.25 & 0.50 & 0.70 & 0.20 \\
\hline & & D4 & 0.00 & 0.00 & 0.00 & 0.00 \\
\hline & & & 2.07 & 2.76 & 2.08 & 1.90 \\
\hline \multirow[t]{10}{*}{$\mathrm{D}$} & \multirow[t]{6}{*}{ Ridge gourd $\left(\mathrm{O}_{4}\right)$} & D0 & 5.95 & 7.50 & 5.15 & 5.00 \\
\hline & & D1 & 3.70 & 4.20 & 3.50 & 3.40 \\
\hline & & D2 & 0.70 & 2.00 & 0.70 & 0.70 \\
\hline & & D3 & 0.25 & 0.60 & 0.40 & 0.25 \\
\hline & & D4 & 0.00 & 0.00 & 0.00 & 0.00 \\
\hline & & & 2.12 & 2.84 & 1.92 & 1.89 \\
\hline & $C D=(P=0.05)$ & & $\mathrm{CD}=(\mathrm{P}=0.05)$ & $\mathrm{CD}=(\mathrm{P}=0.05)$ & $\mathrm{CD}=(\mathrm{P}=0.05)$ & $\mathrm{CD}=(\mathrm{P}=0.05)$ \\
\hline & $\mathrm{O}$ & & 0.11 & 0.18 & 0.09 & 0.09 \\
\hline & $\mathrm{D}$ & & 0.12 & 0.20 & 0.11 & 0.10 \\
\hline & $\mathrm{O} \times \mathrm{D}$ & & 0.24 & 0.41 & 0.22 & 0.20 \\
\hline
\end{tabular}

$\mathrm{D} 0=0.0 \mathrm{ml} / \mathrm{kg} . \quad \mathrm{D} 1=2.0 \mathrm{ml} / \mathrm{kg} . \quad \mathrm{D} 2=4.0 \mathrm{ml} / \mathrm{kg} . \quad \mathrm{D} 3=6.0 \mathrm{ml} / \mathrm{kg} . \quad \mathrm{D} 4=8.0 \mathrm{ml} / \mathrm{kg}$.

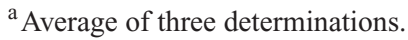


Table 2 Effect of Vegetable Seed Oil Application at Different Level on Milling Fractions and Apparent Degree of Dehusking of Pigeonpea Grain.

\begin{tabular}{|c|c|c|c|c|c|c|c|c|c|c|c|c|c|c|c|c|c|}
\hline \multirow{3}{*}{$\begin{array}{c}\text { Milling } \\
\text { fractions } \\
(\%)\end{array}$} & \multirow{3}{*}{\begin{tabular}{|c|} 
Control \\
D0 \\
\end{tabular}} & \multicolumn{16}{|c|}{ Type of vegetable seed oil used $(\mathrm{mL} / \mathrm{kg})$} \\
\hline & & \multicolumn{4}{|c|}{ Bitter gourd $\left(\mathrm{O}_{1}\right)$} & \multicolumn{4}{|c|}{ Small bitter gourd $\left(\mathrm{O}_{2}\right)$} & \multicolumn{4}{|c|}{ Bottle gourd $\left(\mathrm{O}_{3}\right)$} & \multicolumn{4}{|c|}{ Ridge gourd $\left(\mathrm{O}_{4}\right)$} \\
\hline & & D1 & D2 & D3 & D4 & D1 & D2 & D3 & D4 & D1 & $\mathrm{D} 2$ & D3 & D4 & D1 & D2 & D3 & D4 \\
\hline $\mathrm{T} 1$ & 15.1 & 17.2 & 19.4 & 20.6 & 21.6 & 17.8 & 19.9 & 21.3 & 21.9 & 17.0 & 19.0 & 20.4 & 20.8 & 16.3 & 19.5 & 22.0 & 22.2 \\
\hline $\mathrm{T} 2$ & 17.9 & 17.9 & 19.4 & 22.5 & 23.0 & 17.4 & 20.7 & 24.9 & 24.1 & 17.6 & 20.0 & 23.6 & 24.0 & 18.9 & 21.4 & 23.3 & 23.1 \\
\hline $\mathrm{T} 3$ & 10.6 & 12.1 & 13.0 & 14.5 & 14.0 & 12.8 & 13.1 & \begin{tabular}{|l|}
14.1 \\
\end{tabular} & 13.6 & 12.6 & 14.0 & 14.2 & 14.0 & 11.7 & 12.3 & 13.2 & 13.6 \\
\hline $\mathrm{T} 4$ & 27.2 & 25.4 & 26.4 & 25.5 & 23.8 & 25.5 & 26.1 & 22.8 & 23.7 & 25.6 & 25.5 & 24.1 & 23.3 & 25.6 & 25.3 & 23.9 & 24.0 \\
\hline T5 & 23.8 & 20.4 & \begin{tabular}{|l|l}
14.0 \\
\end{tabular} & 8.5 & 8.2 & \begin{tabular}{|l|l}
19.4 \\
\end{tabular} & 12.3 & 7.1 & 6.9 & 20.2 & 13.6 & 8.6 & 8.3 & 20.6 & 14.1 & 7.9 & 7.3 \\
\hline T6 & 5.4 & 7.0 & 7.8 & 8.4 & 9.4 & 7.1 & 7.9 & 9.8 & 9.8 & 7.0 & 7.9 & 9.1 & 9.6 & 6.9 & 7.4 & 9.7 & 9.8 \\
\hline $\begin{array}{l}\text { Apparent } \\
\text { degree of } \\
\text { dehusking }\end{array}$ & 40.0 & 51.85 & \begin{tabular}{|l|l}
57.78 \\
\end{tabular} & 62.22 & $\mid 69.62$ & 52.59 & 58.52 & \begin{tabular}{|l|}
72.59 \\
\end{tabular} & 72.59 & 51.85 & 58.52 & 67.41 & 71.11 & \begin{tabular}{|l|}
51.1 \\
\end{tabular} & 54.82 & 71.85 & 72.59 \\
\hline
\end{tabular}

$\mathrm{CD}(\mathrm{P}=0.05) \quad \mathrm{T}=0.09, \quad \mathrm{D}=$ N.S., $\quad \mathrm{O}=$ N.S., $\quad \mathrm{T} \times \mathrm{D}=0.18, \quad \mathrm{~T} \times \mathrm{O}=0.18, \quad \mathrm{D} \times \mathrm{O}=$ N.S.,$\quad \mathrm{T} \times \mathrm{D} \times \mathrm{O}=0.37$

Where,

$\begin{array}{rlrl}\mathrm{T} 1 & =\text { Dehusked whole grains (DWG) } & \mathrm{T} 4 & =\text { Undehusked splits (US) } \\ \mathrm{T} 2 & =\text { Undehusked whole grains (UWG) } & & + \text { Partially Dehusked splits (PDS) } \\ & + \text { Partially Dehusked whole grains (PDW) } & \mathrm{T} 5 & =\text { Brokens }+ \text { Germ + Powder (BGP) } \\ \mathrm{T} 3 & =\text { Dehusked splits (DS) } & \mathrm{T} 6 & =\text { Clean Husk }(\mathrm{CH}) \\ \mathrm{D} 0=0.0 \mathrm{ml} / \mathrm{kg} . \quad \mathrm{D} 1=2.0 \mathrm{ml} / \mathrm{kg} . \quad \mathrm{D} 2=4.0 \mathrm{ml} / \mathrm{kg} . & \mathrm{D} 3=6.0 \mathrm{ml} / \mathrm{kg} . & \mathrm{D} 4=8.0 \mathrm{ml} / \mathrm{kg} .\end{array}$

Note : 1 . The native moisture and husk content in the Pigeonpea was estimated as $7.5 \%$ and $13.5 \%$, respectively.

2. Treated samples of Pigeonpea were kept for 60 days at laboratory conditions and then milled.

Table 3 Effect of Vegetable Seed Oil Application at Different Level on Milling Fractions and Apparent Degree Dehusking of Chickpea Grain.

\begin{tabular}{|c|c|c|c|c|c|c|c|c|c|c|c|c|c|c|c|c|c|}
\hline \multirow{3}{*}{$\begin{array}{c}\text { Milling } \\
\text { fractions } \\
(\%)\end{array}$} & \multirow{3}{*}{$\begin{array}{c}\text { Control } \\
\text { D0 }\end{array}$} & \multicolumn{16}{|c|}{ Type of vegetable seed oil used $(\mathrm{mL} / \mathrm{kg})$} \\
\hline & & \multicolumn{4}{|c|}{ Bitter gourd $\left(\mathrm{O}_{1}\right)$} & \multicolumn{4}{|c|}{ Small bitter gourd $\left(\mathrm{O}_{2}\right)$} & \multicolumn{4}{|c|}{ Bottle gourd $\left(\mathrm{O}_{3}\right)$} & \multicolumn{4}{|c|}{ Ridge gourd $\left(\mathrm{O}_{4}\right)$} \\
\hline & & D1 & D2 & D3 & D4 & D1 & $\mathrm{D} 2$ & D3 & D4 & D1 & $\mathrm{D} 2$ & D3 & D4 & D1 & $\mathrm{D} 2$ & D3 & D4 \\
\hline $\mathrm{T} 1$ & 0.4 & 0.6 & 0.9 & 1.4 & 1.5 & 0.8 & 1.1 & 1.6 & 1.3 & 0.5 & 0.5 & 0.9 & 1.2 & 0.7 & 0.9 & 1.2 & 1.3 \\
\hline $\mathrm{T} 2$ & 0.5 & 0.5 & 0.4 & 0.4 & 0.2 & 0.4 & 0.4 & 0.3 & 0.3 & 0.3 & 0.4 & 0.4 & 0.3 & 0.4 & 0.3 & 0.3 & 0.3 \\
\hline $\mathrm{T} 3$ & 64.4 & 64.8 & 66.5 & 73.2 & 74.6 & 66.8 & 70.3 & 75.6 & 75.1 & 67.1 & 66.5 & 72.3 & 74.2 & 66.0 & 66.5 & 71.3 & 75.4 \\
\hline $\mathrm{T} 4$ & 0.9 & 1.5 & 1.0 & 0.5 & 0.5 & 1.6 & 0.9 & 0.4 & 0.6 & 1.0 & 1.1 & 0.9 & 0.9 & 0.9 & 1.0 & 0.8 & 0.7 \\
\hline T5 & 24.1 & 20.6 & 18.0 & 10.4 & 8.2 & 18.1 & 13.1 & 7.1 & 7.4 & 20.1 & 19.2 & 12.4 & 8.6 & 20.1 & 17.3 & 11.7 & 7.0 \\
\hline T6 & 9.7 & 12.0 & 13.2 & \begin{tabular}{|l|l}
14.1 \\
\end{tabular} & \begin{tabular}{|l|l}
15.0 \\
\end{tabular} & 12.3 & 14.2 & 15.0 & 15.3 & 11.0 & 12.3 & 13.1 & \begin{tabular}{|l|l}
14.8 \\
\end{tabular} & 11.9 & 14.0 & 14.7 & 15.3 \\
\hline $\begin{array}{l}\text { Apparent } \\
\text { degree of } \\
\text { dehusking }\end{array}$ & 59.88 & 74.07 & 81.48 & 87.04 & 92.59 & 75.93 & 87.65 & 92.59 & 94.44 & 67.90 & 75.93 & 80.86 & 91.36 & 73.46 & 86.42 & 90.74 & \begin{tabular}{|l|l|}
94.44 \\
\end{tabular} \\
\hline
\end{tabular}

$\mathrm{CD}(\mathrm{P}=0.05) \quad \mathrm{T}=0.12, \quad \mathrm{D}=$ N.S.,$\quad \mathrm{O}=$ N.S., $\quad \mathrm{T} \times \mathrm{D}=0.24, \quad \mathrm{~T} \times \mathrm{O}=0.24, \quad \mathrm{D} \times \mathrm{O}=$ N.S.,$\quad \mathrm{T} \times \mathrm{D} \times \mathrm{O}=0.49$ Where,

$\begin{array}{rllll}\mathrm{T} 1 & = & \text { Dehusked whole grains (DWG) } & \mathrm{T} 4 & =\text { Undehusked splits (US) } \\ \mathrm{T} 2 & =\text { Undehusked whole grains (UWG) } & & + \text { Partially Dehusked splits (PDS) } \\ & + \text { Partially Dehusked whole grains (PDW) } & \mathrm{T} 5 & =\text { Brokens + Germ + Powder (BGP) } \\ \mathrm{T} 3 & =\text { Dehusked splits (DS) } & \mathrm{T} 6 & =\text { Clean Husk }(\mathrm{CH}) \\ \mathrm{D} 0=0.0 \mathrm{ml} / \mathrm{kg} . \quad \mathrm{D} 1=2.0 \mathrm{ml} / \mathrm{kg} . \quad \mathrm{D} 2=4.0 \mathrm{ml} / \mathrm{kg} . \quad \mathrm{D} 3=6.0 \mathrm{ml} / \mathrm{kg} . & \mathrm{D} 4=8.0 \mathrm{ml} / \mathrm{kg} .\end{array}$

Note : 1 . The native moisture and husk content in the Chickpea grain was estimated as $10.0 \% \& 16.2 \%$, respectively.

2. Treated samples of Chickpea grain were kept for 60 days at laboratory condition and then milled. 
Table 4 Effect of Vegetable Seed Oil Application Different Level on Milling Fractions and Apparent Degree of Dehusking of Urdbean Grain.

\begin{tabular}{|c|c|c|c|c|c|c|c|c|c|c|c|c|c|c|c|c|c|}
\hline \multirow{3}{*}{$\begin{array}{c}\text { Milling } \\
\text { fractions } \\
(\%)\end{array}$} & \multirow{3}{*}{\begin{tabular}{|c|} 
Control \\
D0 \\
\end{tabular}} & \multicolumn{16}{|c|}{ Type of vegetable seed oil used $(\mathrm{mL} / \mathrm{kg})$} \\
\hline & & \multicolumn{4}{|c|}{ Bitter gourd $\left(\mathrm{O}_{1}\right)$} & \multicolumn{4}{|c|}{ Small bitter gourd $\left(\mathrm{O}_{2}\right)$} & \multicolumn{4}{|c|}{ Bottle gourd $\left(\mathrm{O}_{3}\right)$} & \multicolumn{4}{|c|}{ Ridge gourd $\left(\mathrm{O}_{4}\right)$} \\
\hline & & D1 & D2 & D3 & $\mathrm{D} 4$ & D1 & $\mathrm{D} 2$ & D3 & D4 & D1 & D2 & D3 & $\mathrm{D} 4$ & D1 & $\mathrm{D} 2$ & D3 & D4 \\
\hline $\mathrm{T} 1$ & 10.1 & 11.4 & 12.3 & 15.1 & 15.1 & 11.6 & 12.2 & 15.4 & 15.3 & 11.0 & 11.8 & 14.5 & 14.8 & 11.0 & 13.8 & 14.2 & 14.6 \\
\hline $\mathrm{T} 2$ & 7.2 & 10.1 & 10.4 & 12.0 & 12.2 & 10.4 & 10.8 & 12.4 & 12.4 & 10.0 & 10.2 & 11.6 & 11.8 & 9.6 & 10.6 & 11.0 & 11.1 \\
\hline $\mathrm{T} 3$ & 25.0 & 24.0 & 27.7 & 33.2 & 33.1 & 23.5 & 29.5 & 32.6 & 32.6 & 24.5 & 31.2 & 31.5 & 31.6 & 26.4 & 27.6 & 29.0 & 29.9 \\
\hline $\mathrm{T} 4$ & 30.4 & 28.4 & 25.6 & 20.2 & 20.0 & 28.6 & 24.4 & 20.0 & 20.0 & 28.4 & 23.4 & 22.6 & 22.1 & 27.0 & 25.0 & 24.8 & 23.9 \\
\hline T5 & 20.2 & 18.0 & 15.6 & 10.4 & 10.2 & 17.5 & 14.1 & 10.0 & 9.9 & 18.1 & 15.2 & 11.2 & 10.6 & 18.4 & 14.6 & 12.2 & 11.5 \\
\hline T6 & 7.1 & 8.1 & 8.4 & 9.1 & 9.4 & 8.4 & 9.0 & 9.6 & 9.8 & 8.0 & 8.2 & 8.6 & 9.1 & 7.6 & 8.4 & 8.8 & 9.0 \\
\hline $\begin{array}{c}\text { Apparent } \\
\text { degree of } \\
\text { dehusking }\end{array}$ & 63.39 & 72.32 & 75.0 & 81.25 & \begin{tabular}{|l|}
83.93 \\
\end{tabular} & 75.0 & 80.36 & 85.71 & 87.50 & 71.42 & 73.21 & 76.79 & 81.25 & 67.86 & 75.0 & 78.57 & 80.36 \\
\hline
\end{tabular}

$\mathrm{CD}(\mathrm{P}=0.05) \quad \mathrm{T}=0.12, \quad \mathrm{D}=$ N.S., $\quad \mathrm{O}=$ N.S., $\quad \mathrm{T} \times \mathrm{D}=0.25, \quad \mathrm{~T} \times \mathrm{O}=0.25, \quad \mathrm{D} \times \mathrm{O}=$ N.S.,$\quad \mathrm{T} \times \mathrm{D} \times \mathrm{O}=0.49$

Where,

$$
\begin{array}{rlrl}
\mathrm{T} 1 & =\text { Dehusked whole grains }(\mathrm{DWG}) & \mathrm{T} 4 & =\text { Undehusked splits } \\
\mathrm{T} 2 & =\text { Undehusked whole grains }(\mathrm{UWG}) & & + \text { Partially Dehusked } \\
& + \text { Partially Dehusked whole grains }(\mathrm{PDW}) & \mathrm{T} 5 & =\text { Brokens }+ \text { Germ }+ \\
\mathrm{T} 3 & =\text { Dehusked splits }(\mathrm{DS}) & \mathrm{T} 6 & =\text { Clean Husk }(\mathrm{CH}) \\
\mathrm{D} 0=0.0 \mathrm{~m} / \mathrm{kg} . & \mathrm{D} 1=2.0 \mathrm{ml} / \mathrm{kg} . \quad \mathrm{D} 2=4.0 \mathrm{ml} / \mathrm{kg} . \quad \mathrm{D} 3=6.0 \mathrm{ml} / \mathrm{kg} . & \mathrm{D} 4=8.0 \mathrm{ml} / \mathrm{kg} .
\end{array}
$$

Note : 1 . The native moisture and husk content of the sample was estimated as $11.5 \% \& 11.2 \%$, respectively.

\begin{tabular}{|c|c|c|c|c|c|c|c|c|c|c|c|c|c|c|c|c|c|}
\hline \multirow{3}{*}{$\begin{array}{c}\text { Milling } \\
\text { fraction } \\
(\%)\end{array}$} & \multirow{3}{*}{\begin{tabular}{c|} 
Control \\
D0 \\
\end{tabular}} & \multicolumn{16}{|c|}{ Table of vegetable seed oil used $(\mathrm{ml} / \mathrm{kg})$} \\
\hline & & \multicolumn{4}{|c|}{ Bitter gourd $\left(\mathrm{O}_{1}\right)$} & \multicolumn{4}{|c|}{ Small bitter gourd $\left(\mathrm{O}_{2}\right)$} & \multicolumn{4}{|c|}{ Bottle gourd $\left(\mathrm{O}_{3}\right)$} & \multicolumn{4}{|c|}{ Ridge gourd $\left(\mathrm{O}_{4}\right)$} \\
\hline & & D1 & $\mathrm{D} 2$ & D3 & D4 & D1 & $\mathrm{D} 2$ & D3 & D4 & D1 & $\mathrm{D} 2$ & D3 & D4 & D1 & $\mathrm{D} 2$ & D3 & D4 \\
\hline $\mathrm{T} 1$ & 11.2 & 12.1 & 12.8 & 10.0 & 15.4 & 12.0 & 13.4 & 15.4 & 15.5 & 12.4 & 12.8 & 13.4 & 14.2 & 11.8 & 12.6 & 13.4 & 14.2 \\
\hline $\mathrm{T} 2$ & 0.0 & 7.2 & 8.4 & 8.8 & 9.1 & 6.9 & 8.6 & 10.1 & 10.2 & 7.4 & 7.8 & 8.2 & 9.1 & 7.0 & 7.9 & 8.4 & 8.9 \\
\hline $\mathrm{T} 3$ & 30.1 & 34.2 & 36.6 & 38.1 & 38.3 & 34.4 & 36.5 & 38.8 & 39.0 & \begin{tabular}{|l|}
30.4 \\
\end{tabular} & 34.2 & 36.6 & 37.2 & 30.4 & 35.1 & 36.2 & 37.1 \\
\hline $\mathrm{T} 4$ & 28.8 & 24.1 & 24.4 & 23.1 & 22.4 & 25.5 & 23.9 & 20.7 & 20.3 & 27.8 & 25.7 & 23.5 & 23.5 & 29.3 & 26.8 & 25.7 & 23.6 \\
\hline $\mathrm{T} 5$ & 18.2 & 15.2 & 10.4 & 6.9 & 6.6 & 14.2 & \begin{tabular}{|l|}
10.1 \\
\end{tabular} & 6.6 & 6.5 & 15.0 & 12.1 & 10.2 & 7.8 & 14.4 & 10.2 & 8.4 & 8.2 \\
\hline T6 & 6.1 & 7.2 & 7.4 & 8.1 & 8.2 & 7.0 & 7.5 & 8.4 & 8.5 & 7.0 & 7.4 & 8.1 & 8.2 & 7.1 & 7.4 & 7.9 & 8.0 \\
\hline $\begin{array}{l}\text { Apparent } \\
\text { degree of } \\
\text { dehusking }\end{array}$ & 57.00 & 67.29 & \begin{tabular}{|l|}
69.16 \\
\end{tabular} & 75.70 & \begin{tabular}{|l}
76.64 \\
\end{tabular} & 65.42 & \begin{tabular}{|l|}
70.09 \\
\end{tabular} & 78.50 & 79.43 & 65.42 & 69.16 & \begin{tabular}{|l|l|}
75.70 \\
\end{tabular} & 76.64 & 66.36 & \begin{tabular}{|l|}
69.16 \\
\end{tabular} & 73.83 & \begin{tabular}{|l|l}
74.77 \\
\end{tabular} \\
\hline
\end{tabular}

2. Treated samples of Black gram were kept for 60 days at laboratory conditions and then milled.

Table 5 Effect of Vegetable Seed Oil Application at Different Level on Milling Fractions and Apparent Degree of Dehusking of Mungbean Grain.

$\mathrm{CD}(\mathrm{P}=0.05) \quad \mathrm{T}=0.16, \quad \mathrm{D}=$ N.S., $\quad \mathrm{O}=$ N.S., $\quad \mathrm{T} \times \mathrm{D}=0.32, \quad \mathrm{~T} \times \mathrm{O}=0.32, \quad \mathrm{D} \times \mathrm{O}=$ N.S.,$\quad \mathrm{T} \times \mathrm{D} \times \mathrm{O}=0.65$ Where,

$$
\begin{array}{rlrl}
\mathrm{T} 1 & =\text { Dehusked whole grains (DWG) } & \mathrm{T} 4 & =\text { Undehusked splits (US) } \\
\mathrm{T} 2 & =\text { Undehusked whole grains (UWG) } & & + \text { Partially Dehusked splits (PDS) } \\
& + \text { Partially Dehusked whole grains (PDW) } & \mathrm{T} 5 & =\text { Brokens + Germ + Powder (BGP) } \\
\mathrm{T} 3 & =\text { Dehusked splits (DS) } & \mathrm{T} 6 & =\text { Clean Husk }(\mathrm{CH}) \\
\mathrm{D} 0=0.0 \mathrm{ml} / \mathrm{kg} . \quad \mathrm{D} 1=2.0 \mathrm{ml} / \mathrm{kg} . \quad \mathrm{D} 2=4.0 \mathrm{ml} / \mathrm{kg} . & \mathrm{D} 3=6.0 \mathrm{ml} / \mathrm{kg} . & \mathrm{D} 4=8.0 \mathrm{ml} / \mathrm{kg} .
\end{array}
$$

Note : 1 . Native moisture and husk content of the sample was estimated as $8.7 \%$ and $10.7 \%$, respectively.

2. Treated samples of Mungbean grain were kept for 60 days at laboratory conditions and then milled. 
and Chickpea grains. It is clear from the Table 4 and Table 5 that apparent degree of dehusking is maximum in case of use of small bitter gourd seed oil at the dose rate of 8 $\mathrm{mL} / \mathrm{kg}$, i.e. 87.50 and $79.43 \%$ in Urdbean and Mungbean, respectively. Which is due to the anti-insect property/ activity of extracted seed oils. This insecticidal property of vegetable seed oil may be due to the some alkaloids present in the extracted oils which is in accordance to the views of R.F. Heal and E.F. Rogers ${ }^{17}$. As these researchers have made a survey of plants for insecticidal property and have reported that an alkaloid "Momordicin" is responsible for bitter taste, which possesses bacteriostatic and insecticidal properties. Thus out of all four vegetable seed oil used the result indicates the effectiveness of Small bitter gourd seed oil is maximum in comparison to other vegetable seed oil used.

\section{CONCLUSION}

The result of this study indicated better efficiency of vegetable seed oil application at $6 \mathrm{~mL} / \mathrm{kg}$ level in legumepulse grains as grain protectant against infestation as wells as for quantitative dehusking in its milling. From the present study it is concluded that small bitter gourd seed oil is most effective at the application level of $6 \mathrm{~mL} / \mathrm{kg}$, as weight loss for all the legume-pulse grains is almost negligible after use and also the apparent degree of dehusking is maximum with minimum BGP fraction as compared to other oils. The seed oil of Ridge gourd also yielded good result in case of Pigeonpea and Chickpea grains while in case of Urdbean and Mungbean the result are better with application of Bitter gourd seed oil. The effectiveness of Small bitter gourd seed oil was observed to be more in comparison to other vegetable seed oils of Cucurbitaceae family used, which may be due the presence of momordicin alkaloid in the oil. Therefore, from this study it may be concluded that vegetable seed oils may be used as a satisfactory protectant for insect infestation in pulse grains which also inturn helps in the improved milling yields with better degree of dehusking of legume-pulse grains. Although the objectives set out for this research have been fulfilled, the scale up studies are required to understand the action mechanism as protectant of solvent extracted vegetable seed oil of Cucurbitaceae family on legume-pulse grain storage, which shall be beneficial for common masses in replacing the use of harmful chemicals to environment friendly, vegetable seed oil base bio- insecticide.

\section{References}

1. Matthews, G.A. Insecticide application in stores, application technology for crop protection. CAB. London. 305-315 (1993).

2. Zettler, J.L.; Cuperus, G.W. Perticide resistance in tribolium costaneum and rhyzopertha dominica in wheat. J. Econ. Entomal. 83, 1677-1681 (1990).

3. Champ, B.R.; Dyte, C.E. Report of the FAO global survey of pesticide susceptibility of stored grain pests. Plant Prod. Prot. Bull. 5 (1976).

4. Tripathi, A.K.; Prajapati, V.; Gupta, R.; Kumar, S. Herbal material for the insect - pest management in stored grains under tropical conditions. J. Med. Aromat. Plant Sci. 27, 408-430 (1999).

5. Mishra, D.; Shukla, A.K.; Dixit, A.K.; Singh, K. Aqueous enzymatic extraction of oil from mandarin peels. $J$. Oleo Sci. 54, 355-359 (2005).

6. Shaaya, E.; Ravid, U.; Padter, N.; Juven, B.; Zisman, U.; Pissarev, V. Fumigant toxicity of essential oils against four major stored product insects. J. Chem. Ecal. 17, 499-504 (1991).

7. Weaver, D.K.; Phillips, T.W.; Dunkel, F.V.; Weaver, T.; Srubb, R.T.; Nance, E.L. Dried leaves from rocky mountain plants decrease infestation by stored product beetles. J. Chem. Ecol. 21, 127-142 (1995).

8. Feistein, L. Insecticides from plants insect, year book of agriculture, U.S.O.A. Washington. 222-229 (1952).

9. Lal R.; Pradhen, S. A Critical review of toxicological investigation on insect pest of agriculture importance in India. I.C.A.R. 1-48 (1997).

10. Mishra, D.; Shukla, A.K,; Dubey, A.K.; Dixit, A.K.; Singh, K. Insecticidal activity of vegetable oils against mustard aphid, Lipaphis Erysimi kalt. under Field Condition. J. Oleo Sci. 55, 217-223 (2005).

11. Mookherjee, P.B.; Jotwani, M.G.; Yadav, T.D.; Sircar, P. Studies on incidence and extent of damage due to insect pests in stored seeds. Indian J. Ent. 32, 350-355 (1970).

12. Pandey, G.P.; Shanker, S.; Gupta, P.C. Occurrence of pulse beetle in the fields of ghazibad district (U.P.). Bull. Grain Technical. 21, 160-162 (1983).

13. Patnaik, H.P. Note on field infestation of pigeonpea by C. chinesis in orissa, Bul. Grain Technical. 22, 259-260 (1984).

14. Golob, P.; Webley, D.T. The use of plants and minerals as traditional protectants of stored products, Reports of the tropical products institute, G138, 32 (1980).

15. Seshadra, V.S. Vegetable crops in India, agricultural hurticultral publishing house. Nagpur. India, 91-163 (1987).

16. Pomeranz, Y.; Meloan, C.F. Food analysis theory and practice. 3rd. Van Nostrand Reinhold. New York (1994).

17. Heal, R.F.; Rogers, E.F. A survey of plants for insecticidal activity. Lloydia. 13, pp. 89-162 (1950). 